\title{
Covid-19 Salgın Sürecinde Zorunlu Uzaktan Eğitim Alan Öğrencilerin Teknoloji Kabulü ve Topluluk Hissinin Memnuniyete Katkısının İncelenmesi: KKTC Örneği
}

\section{Investigation of the Contribution of Students Receiving Compulsory Distance Education to Technology Acceptance and Community Feeling to Satisfaction During the Covid-19 Pandemic Process: An Example of Northern Cyprus}

\author{
Hüseyin GÖKAL ${ }^{l,}$, Volkan CANTEMIR ${ }^{2}$, Vesile KÜÇÜK ${ }^{3}$
}

\begin{abstract}
${ }^{1}$ Sorumlu Yazar, Öğr. Görevlisi, Hüseyin GÖKAL, Bilgisayar Teknolojileri Bölümü, Meslek Yüksekokulu, İstanbul Esenyurt Üniversitesi, Türkiye, huseyingokal@esenyurt.edu.tr, (https://orcid.org/0000-0001-5687-7715)

${ }^{2} O \ddot{g} r$. Görevlisi, Volkan CANTEMIR, Bilgisayar Teknolojileri Bölümü, Meslek Yüksekokulu, Istanbul Esenyurt Üniversitesi, Türkiye, volkancantemir@esenyurt.edu.tr, (https://orcid.org/0000-0002-6632-8151)

${ }^{3}$ Dr. Öğr. Üyesi, Vesile KÜÇÜK, Bilgisayar Teknolojileri Bölümü, Meslek Yüksekokulu, İstanbul Esenyurt Üniversitesi, Türkiye, vesilekucuk@esenyurt.edu.tr, (https://orcid.org/0000-00018186-1563)
\end{abstract}

Geliş Tarihi: 02.06.2021

Kabul Tarihi: 04.12 .2021

ÖZ

$\mathrm{Bu}$ çalışmada, salgın süresince çevrimiçi eğitim gören öğrencilerin memnuniyetleri, topluluk hissi ve teknoloji kabul ölçeği kullanılarak araştırılmıştır. Çalışmada, ilişkisel ve betimsel araştırma modeli kullanılmıştır. Kullanılan ölçeklerin uygulandığı araştırma grubu, KKTC'de bulunan Uluslararası Kıbrıs Üniversitesinde 2020-2021 güz yarıyılında uzaktan öğrenim gören 406 üniversite öğrencisi oluşturmuştur. Veri analizi aşamasında kanonik korelasyon analizi, çoklu regresyon analizi, çoklu aşamalı regresyon analizi ve betimsel istatistikler kullanılmıştır. Verilerin analizi sırasında SPSS 24 yazılımı kullanılmıştır. Elde edilen neticelere göre; öğrenci memnuniyeti ile topluluk hissi ve teknoloji kabulü arasında pozitif ve yüksek seviyede ilişki olduğu belirlenmiştir. Çevrim içi öğrenme sistemlerinde duyuşsal değişkenin öğrencilerin, çevrim içi uzaktan eğitim-öğretime yönelik memnuniyetlerinin öğrenmeleri açısından yararlı olduğu ortaya çıkmıştır. Duyuşsal, eylemsel ve algılanan kolaylık değişkenlerinin üniversite öğrencilerinin uzaktan eğitime yönelik memnuniyetlerine anlamlı ve pozitif bir etkisi olduğu, algılanan yarar değişkeninin anlamlı fakat negatif bir etkisi saptanmıştır. Bu sonuca göre üniversite öğrencilerinin yüz yüze eğitimi daha yararlı gördükleri anlaşılmaktadır. Çevrim içi öğrenme sistemlerinde duyuşsal değişken ve algılanan yarar boyutları, topluluk hissi ve kabul ölçeği boyutlarının memnuniyet boyutları ile ilişkisi incelendiğinde en yüksek değerleri veren değişkenler olduğu görülmüştür.

Anahtar Sözcükler: Topluluk Hissi, çevrim içi öğrenme sistemleri, uzaktan eğitim, salgın, Covid-19.

\section{ABSTRACT}

In this study, the contribution to satisfaction for online distance education students was investigated using the community feeling and technology acceptance scale. The descriptive and relational research model was used. The research group, in which the scales used were applied, consisted of 406 university students 
studying distance education at Cyprus International University in the KKTC in the fall semester of 20202021. In the data analysis section, descriptive statistics, multiple regression analysis, stepwise multiple regression analysis, and canonical correlation analysis were used. SPSS 24 software was used for the analysis of the data. According to the findings obtained; It has been determined that there is a positive and high level of relationship between technology acceptance and a sense of community and student satisfaction. It has been found that students who find the affective variable useful for learning in online learning systems have more satisfaction with distance education. While affective, operational, and perceived convenience variables had a significant and positive effect on university students' satisfaction with distance education, the variable of perceived usefulness was found to have a significant but negative effect. According to this result, it is understood that university students see face-to-face education as more beneficial. When the relationship between the dimensions of affective variable and perceived usefulness, sense of community and acceptance scale and satisfaction dimensions in online learning systems was examined, it was seen that the variables with the highest values were found.

Keywords: Community feeling, online learning systems, distance learning, pandemic, Covid-19.

\section{GIRIŞ}

Bilgi ve teknoloji çağı olarak adlandırılan içinde bulunduğumuz yüzyıl, eğitimin de çehresini değiştirmiştir. Teknoloji sayesinde eğitimde zaman ve mekân sınırları ortadan kaldırılıp bireyin bilgiye daha hızlı ulaşması sağlanmıştır. Eğitime farklı bir boyut kazandıran bu teknolojik gelişmeler eğitimde firsat eşitliğini ön plana çıkarmıştır. Eğitimi belli bir kalıptan çıkaran bu model uzaktan eğitim kavramı olarak anılmaya başlamıştır. Uzaktan eğitimi Karatepe ve diğerleri (2020), hayat boyu öğrenme imkânı sunan, bireyin eğitim ihtiyaçlarını karşılayan, teknoloji sayesinde kendi kendine öğrenimi gerçekleştiren bir disiplin olarak belirtmiştir. Uzaktan eğitim yeni ortaya çıkmış bir kavram değildir. Türkiye'de Yükseköğretim kurumlarında uzun süredir uygulanan bu sistem birçok üniversitede lisansüstü düzeyde yapılmak ile birlikte yüz yirmi üniversitenin bünyesinde uzaktan eğitim sistemi bulunmaktadır (Karadağ ve Yücel, 2020). 1700'lü yıllara dayanan bu süreç bilişim sistemlerinin gelişmesiyle değişiklik göstermiştir. Uzaktan Eğitimin tarihine kronolojik bir şekilde bakılacak olursa ilk evre mektupla, ikinci evre radyo ve televizyon, üçüncü evre canlı telefon bağlantıları ve canlı televizyon bağlantıları ve son evre esnek öğrenme yöntemi olarak gösterilmektedir (Cantemir ve Nat, 2019). Covid-19 salgını ile birlikte hayatımıza hızlı bir giriş yapan uzaktan eğitim süreci destekleyici bir öğretim yöntemi yerine asıl bir zemin olarak yerini almıştır (Telli ve Altun, 2021). Salgın koşulları hayatımızın her alanını değiştirdiği gibi eğitim ve öğretim faaliyetlerinde de köklü bir değişim yarattı. Salgın ile dijitalleşen dünya 2020 yılında eğitim-öğretim faaliyetlerini de zorunlu olarak dijital ortama, çevrim içi ortama taşımak zorunda kaldı (Bozkurt, 2020). Salgın koşulları sebebiyle eğitimöğretim faaliyetleri açısından dünyanın en büyük değişikliği gerçekleştirilip 1.6 milyar öğrenci çevrimiçi uzaktan eğitim yöntemine göre öğrenimlerine devam etmiştir (Anderson, 2020). İçinde bulunduğumuz esnek öğrenme yönteminde öğrenciler fiziki etkileşim olmadan eğitim ve öğretim faaliyetlerinin yürütülmesi için televizyon, bilgisayar, tablet ve akıllı telefonu gibi araç gereçlerden yararlanmaktadırlar (Karakuş, Ucuzsatar, Karacaoğlu, Esendemir ve Bayraktar, 2020). Uzaktan eğitim için öğrenciler genel olarak bilgisayar ve akıllı telefonları tercih etmektedirler. Gökal ve Adalıer (2021) tarafından yapılan araştırmada üniversitede öğrenim gören öğrencilerin hayatlarının her alanında akıllı telefonlarını kullandıkları görülmektedir. $\mathrm{Bu}$ araştırmanın demografik veriler anket sonuçlarında görüldüğü üzere üniversite öğrencilerinin \%31.8'i uzaktan eğitim sürecinde akıllı telefonlarını kullanmaktadır.

Uzaktan eğitim son yıllarda, coğrafi engeller, artan eğitim ihtiyacı ve zaman kısıtlamaları gibi nedenlerle bireyler tarafından oldukça talep gören bir seçenek hâline gelmiştir. 2019 yılı 1 Aralık'ta Çin'in Wuhan kentinde ortaya çıkan Koronavirüs (Covid-19) salgını ile birlikte tüm eğitim kademelerinde zorunlu uzaktan eğitime geçiş süreci yaşanarak uzaktan eğitimin önemi bir kat daha artmıştır. Koronavirüs çok kısa bir zaman zarfinda geniş coğrafyalara yayılarak tüm dünya ülkeleri üzerinde etkisini göstermiştir. İnsanların günlük yaşantısını olumsuz yönde 
etkileyen bu salgın sağlık başta olmak üzere ulaşım, turizm, ekonomi, finans, gıda, kültür alanlarında kısıtlamalara yol açmıştır. Bu süreç eğitimi de etkilemiştir. Eğitim konusunda alınan ilk önlem okulların kapatılıp, yüz yüze verilen eğitime ara verilmesi yönünde olmuștur. 12 Mart 2020 tarihinde gerçekleşen Koronavirüse karşı alınacak tedbirlerin görüşüldüğü hükümet toplantısı sonrasında Milli Eğitim Bakanlığına bağlı ilk ve ortaöğretim okullarının 16 Mart 2020 tarihi itibari ile bir hafta tatil edilerek, 23 Mart 2020 tarihi itibariyle uzaktan eğitime geçileceği kararı açıklanmıştır. Aynı zamanda bu toplantıda 16 Mart 2020 tarihinden itibaren üniversitelerin de eğitimlerine üç hafta ara verileceği ve bu süre zarfında eğitimin nasıl telafi edileceği ve ne şekilde devam ettirileceği kararının Yüksek Öğretim Kurulu (YÖK) koordinasyonunda belirleneceği ifade edilmiştir (Haberler: TCCB, 2020). Daha sonra yapılan toplantılarda da salgın süreci kapsamında, üniversitelerde yüz yüz eğitime ara verilmiş, uzaktan eğitime geçilerek derslerin ve sınavların web tabanlı olarak devreye alınmasına karar verilmiştir (Keskin ve Derya, 2020). Dünyadaki eğitim kurumları, öğrenmenin sürekliliğini sağlamak amacıyla, uzaktan eğitim vermek için sivil toplum, özel sektör ortakları ve uluslararası kuruluşlarla birlikte ortaklaşa çalışmalar başlatmıştır (Can, 2020).

Uzaktan eğitim ile ilgili araştırmalar incelendiğinde öğretmenler ve öğrenciler açısından bu kavramın avantajları ve dezavantajları olduğu görülmektedir. Uzaktan eğitimin avantajları ve dezavantajlarını aşağıdaki gibi açıklanmaktadır (Eygü ve Karaman, 2013).

Avantajlar1;

- Öğrencilerin yaşam boyu öğrenme gereksinimleri karşılanabilmektedir.

- Bireysel ve bağımsız ögrenme olanağı sağlamakla beraber öğrenme sorumluluğunun öğrencide olması kendisini geliştirmeye ve karar verme yeteneklerinin gelişmesinde etkili olacaktır.

- Öğrenme ve öğretme ortamı, yöntem ve teknikler açısından çeşitlilik sağlamaktadır.

- Uzaktan eğitim sistemleri kullanıcıya göre maliyet olarak daha uygundur.

- Kamu ve özel kurumlarda çalışan bireylerin, işlerini bırakmadan eğitim ve öğretimi sürdürebilmelerine, kendilerini istedikleri alanda geliştirme ve mesleklerinde yükselme olanağı sağlamaktadır.

- Alternatif öğrenme imkânları sağlar.

- Eğitim programlarının standardizasyonunu sağlar.

Dezavantajları;

- Derslerin uygulama kısmında öğrencilerin konu bazlı eksiklerinin oluşmasına yol açmaktadır.

- Bireysel çalışma alışkanlığı olmayan öğrenciler açısından etkili olmayabilir.

- Çalışan öğrencilerin dinleme için ayrılan zamanlarında uzaktan eğitim derslerine katılmaları kendilerine zaman ayıramamasına yol açmaktadır.

- Sosyalleşme açısından öğrencileri olumsuz etkileyebilir.

- Uzaktan eğitim için kullanılan materyallerin (bilgisayar, akıllı cep telefonu vs.) temini ve teknik sorunlar ortaya çıkabilir.

- Derslerin verimi düşük geçmektedir. Ders için kullanılan çoklu ortam olanaklarının arttırılması bile verimliliğin sadece belirli bir oranda arttırdı̆̆ görülmektedir.

Yaşanılan bu salgın sürecinde uzaktan eğitim tüm dezavantajlarına karşılık öğrenciler açısından eğitim-öğretim hayatının devamlılı̆̆ını sağlamıştır. Eğitmenler ve öğrenciler tarafından uzaktan eğitim sistemi örgün öğretime alternatif olarak görülse de bu sistem yüz yüze eğitim 
kadar etkili bir seçenektir (Başar, Arslan, Günsel ve Akpınar, 2019). Gökal ve diğerleri 2020 yılında yapmış olduğu fen bilgisi öğretmen adaylarının bilgisayar destekli eğitimde tutumlarının pozitif olduğu sonucuna varılmıştır. Öğretmen adaylarının uzaktan eğitim sürecini kabul ettiği söylenmektedir. Uzaktan eğitim ile 1 yıllık zorunlu olarak öğrenim görülen, 2020 ve 2021 yılları 2 yarıyılı incelendiğinde daha fazla kayba yol açmadan ulusal çevrimiçi eğitim rehberi yanı sıra, eğitimin geleceği ve yeni dönemlerde nasıl planlanıp harmanlanacağı tespit edilmelidir (Telli ve Altun, 2021). Dijital öğrenme ve e-öğrenmenin etkili bir hale geldiğini söyleyebiliriz. Bu etkilerin teknoloji geliştikçe VR (Sanal gerçeklik) ve AR (Artırılmış gerçeklik) ile desteklendiğinde etkisi ilerleyen dönemlerde daha da artış gösterecektir (Yamamoto, Özgeldi ve Altun, 2018).

Topluluk Hissi: Topluluk hissini bireyin kendini bir topluluğa ait hissetmesi ve topluluktaki diğer kişiler tarafından önemli olduğunu hissetmesi olarak tanımlanmışlardır (Enfiyeci ve Filiz, 2019).

Teknoloji Kabulü: Teknoloji Kabul Modeli, kitleler içerisinde bilişim teknolojilerini 3 temele dayanarak teknoloji kullanım niyetini ve isteklerini ölçen bir teori olarak tanımlanır (Legris ve diğerleri, 2003).

\section{1. Çalışmanın Amacı}

Bu araştırmanın amacı Covid-19 sürecinde zorunlu olarak tüm derslerine çevrimiçi olarak devam eden üniversite öğrencilerinin teknoloji kabulü ve topluluk hissinin uzaktan eğitim süreçlerine etkisini araştırmaktır.

\section{2. Çalışmanın Önemi}

İçinde bulunduğumuz salgın sürecinde eğitimin, çevrimiçi uzaktan eğitim portalları sayesinde yapılması eğitimin-öğretim sürecinin belirli bir kısmını karşılasa da eksikleri olduğu da görülmektedir. Uzaktan eğitimin daha etkili ve verimli olması adına öğrenci memnuniyetinin önemi artmıştır. Uzaktan eğitim sistemlerinin öğrencilerin sosyal yaşantıları açısından da öğrenciöğretmen ve öğrenci-öğrenci etkileşimi fiziksel ortamlarda yapılmadığından, öğrencilerde topluluk hissinin gelişmemesi yönünde eksiklikleri bulunmaktadır. Bu nedenlerden dolayı uzaktan eğitim ortamlarındaki öğrencilerin memnuniyetlerinin teknoloji kabul modeli değişkenlerinden algılanan kullanım kolaylığ ile topluluk hissi bileşenlerinin ve algılanan yararın katkısının araştırılması önem taşımaktadır. Bu çalışmanın alanyazına etkisi zorunlu olarak geçiş yapmış olduğumuz uzaktan eğitim sürecinde üniversite öğrencilerinin bu geçişi kabul edip etmediklerini farklı değişkenler açısından incelemektir.

\subsection{Problem Cümlesi}

Teknoloji kabulü ve topluluk hissinin KKTC'de zorunlu olarak uzaktan eğitim alan öğrencilerin memnuniyetlerine katkısı nedir?

\subsection{Hipotezler}

H1: Çevrim içi öğrenmeleri kabul ve topluluk hissi bir arada KKTC'de öğrenim gören öğrencilerin memnuniyetine anlamlı bir şekilde yordamakta mıdır?

H2: Çevrim içi öğrenme sistemleri kabul ölçeği alt boyutları ve topluluk hissi ölçeği alt boyutları bir arada KKTC'de öğrenim gören öğrencilerin memnuniyetine anlamlı bir şekilde yordamakta midir?

H3: Çevrim içi öğrenme sistemleri kabul ölçeği boyutları ve topluluk hissi ölçeği boyutları ile KKTC'de öğrenim gören öğrencilerin memnuniyeti ölçeği boyutları arasında bir şekilde yordamakta midir? 


\section{YÖNTEM}

Bu bölümde araştırma modeli ve verilerin analizi, evren ve örneklem, veri toplama ve veri toplama araçları ile ilgili içerikler yer almaktadır.

\subsection{Araștırma Modeli ve Veri Analizi}

$\mathrm{Bu}$ araştırma da değişkenler arasında ilişki bulunup bulunmadığı araştırılmıştır. Bu sebeple araştırma da betimsel ve ilişkisel araştırma modeli tercih edilmiştir. Araştırma sürecinde; toplanan veri analizinde "çoklu regresyon analizi", "çoklu aşamalı regresyon analizi" ve "kanonik korelasyon analizi” kullanılmıştır. Verilerin analizi sırasında SPSS 24 yazılımı kullanılmıştır.

\subsection{Evren ve Örneklem}

$\mathrm{Bu}$ araştırmanın evrenini, KKTC'de öğrenim gören ve Covid-19 salgını sürecinde zorunlu olarak tüm derslerinde uzaktan eğitim yöntemleri ile öğrenim gören üniversite öğrencileri oluşturmaktadır. Araştırmanın örneklemini Uluslararası Kıbrıs Üniversitesinde öğrenim gören en az bir yarıyıl boyunca tüm derslerinde uzaktan eğitim yöntemleri ile öğrenim görmüş 406 üniversite öğrencisi oluşturmuştur. Öğrencilerin demografik bilgilerine Tablo 1'de yer verilmiştir.

Tablo 1. Demografik Veriler

\begin{tabular}{llll}
\hline Demografik veriler & Frekans & Yüzde \\
\hline Yaş & 25 ve Altı & 375 & 92,4 \\
& $26-35$ & 24 & 5,9 \\
& $36-45$ & 1 &, 2 \\
& 45 ve Üstü & 6 & 1,5 \\
Cinsiyet & Toplam & 406 & 100,0 \\
& & Frekans & Yüzde \\
& Erkek & 178 & 43,8 \\
Derslere Erişim & 228 & 56,2 \\
Sağladığı Cihaz & Kadın & 406 & 100,0 \\
& Toplam & Frekans & Yüzde \\
& Tablet & 264 & 65,0 \\
& Akılllı Telefon & 13 & 3,2 \\
& Toplam & 129 & 31,8 \\
Uyruk & & 406 & 100,0 \\
& TC & Frekans & Yüzde \\
& KKTC & 367 & 90,4 \\
& Diğer & 38 & 9,4 \\
& Toplam & 1 &, 2 \\
& & 406 & 100,0 \\
\hline
\end{tabular}

\subsection{Veri Toplama Araçları}

Çalışmada "Google Formlar" yazılımı vasıtasıyla çevrim içi anket uygulanmıştır. Veriler toplanırken öğrencilerin bağlı oldukları uzaktan eğitim derslerinde anket çevrimiçi bağlantısı 
paylaşılmış öğrencilerin katılımı sağlanmıştır. Çalışmaya katılım gönüllülük esasında olmuştur. Çalışmada 406 üniversite öğrencisinden veriler toplanmış ve analiz edilmiştir.

Veri toplama araçları dört bölümden oluşmaktadır;

- Kişisel (dmografik) bilgiler anketi,

- Çevrimiçi öğrenim sistemleri kabul ölçeği,

- Topluluk hissi ölçeği,

- Memnuniyet ölçeği.

Kişisel (Demografik) Bilgi Anketi: Anketin demografik verileri ile ilgili bölümde, öğrencilerin yaşları, cinsiyetleri, derslere erişim sağladığı cihazlar ve ile ilgili sorular yer almaktadır.

Çevrimiçi Öğrenme Sistemleri Kabul Ölçeği: Ölçeğin Türkçe uyarlaması ve geçerlik güvenirlik çalışmaları 574 üniversite öğrencisi katılımıyla gerçekleşmiş ve elde edilen veriler ile analizleri yapılmıştır (Ilgaz, 2008). Elde edilen ölçek 7'li Likert tipinde hazırlanmıştır bunlar; "1: "Kesinlikle Katılmıyorum", 2: "Çoğunlukla Katılmıorum", 3: "Kısmen Katılmıorum", 4: "Kararsızım", 5: "Kısmen Katılıyorum", 6: "Çoğunlukla Katılıyorum", 7: "Kesinlikle Katılıyorum". Ölçek geçerlik güvenirlik çalışmaları neticesinde, " $[\chi 2(8, N=574)=60.10, p<.000$, RMSEA = 0.11, S-RMR= 0.024, GFI= 0.97, AGFI= 0.91, CFI $=0.98, \mathrm{NNFI}=0.97, \mathrm{IFI}=0.98] ”$. Güvenirlik analizi katsayısı alt boyutlar için sırasıyla algılanan kullanım kolaylığı için $0.90 \mathrm{ve}$ algılanan yarar faktörü için 0.93 olarak saptanmıştır (Ilgaz, 2008). Algılanan kullanım kolaylığ ve algılanan yarar olmak üzere 2 faktör ve toplam 6 maddeden oluşmaktadır.

Topluluk Hissi Ölçeği: Ölçek (Ilgaz, 2008)' tarafından uyarlanmış ve geçerlik güvenirlik testleri yapılmıştır. Ölçek 7'li Likert tipinde hazırlanmıştır. Ölçek uyarlama sürecinden 571 üniversite öğrencisinden veriler toplanmış ve analizleri yapılmıştır. " 2 ( $(7, \mathrm{~N}=571)=24.76, \mathrm{p}<$. 000, RMSEA $=0.067, \mathrm{~S}-\mathrm{RMR}=0.034$, GFI $=0.99$, AGFI $=0.96, \mathrm{CFI}=0.99, \mathrm{NNFI}=0.98, \mathrm{IFI}=$ 0.99]". Güvenirlik analizi katsayısı alt boyutlar için sırasıyla Duyuşsal 0.79 ve eylemsel alt boyutu için 0.73 ve toplam ölçek için 0.80 olarak saptanmıştır (Ilgaz, 2008). Ölçek uyarlama süreci sonucunda 6 maddeden oluşan, duyuşsal ve eylemsel olmak üzere 2 faktörlü yapı doğrulanmıştır.

Memnuniyet Ölçeği: Ilgaz (2008) tarafından öğrenci memnuniyetini ölçmek için geliştirilen ölçekte 38 madde bulunmaktadır. Ölçek 7'li Likert tipinde tasarlanmıştır. 360 üniversite ögrencisinden toplanan verileri sonucunda ölçeğin geçerlik, güvenirlik çalışmaları yapilmıştır. " $[\chi 2(509, \mathrm{~N}=360)=1506.29, \mathrm{p}<.000, \mathrm{RMSEA}=0.074, \mathrm{~S}-\mathrm{RMR}=0.067, \mathrm{GFI}=0.80$, AGFI $=0.77, \mathrm{CFI}=0.98, \mathrm{NNFI}=0.98, \mathrm{IFI}=0.98] "$. Güvenirlik analizi katsayısı alt boyutlar için sırasıyla öğrenci ve öğrenci etkileşimi 0.95 , öğrenci ve öğretmen etkileşimi 0.96 , çevrimiçi dersler 0.90 , teknik destek 0.93 , basılı materyal 0.90 ve yüz yüze etkinlikler faktörü 0.89 olarak saptanmıştır (Ilgaz, 2008). Uyarlama sonucunda ölçeğin 38 madde ve 6 faktörlü yapısı doğrulanmıştır.

\section{BULGULAR}

$\mathrm{Bu}$ bölümde araştırma da toplanan veriler incelenerek ve analizleri yapılarak sonuçlara ulaşılmıştır.

H1: Çevrimiçi öğrenmeleri kabul ve topluluk hissi bir arada KKTC'de öğrenim gören öğrencilerin memnuniyetine anlamlı bir şekilde yordamakta mıdır? 
Tablo 2. Korelasyon Tablosu

\begin{tabular}{lllllll}
\hline \multicolumn{2}{l}{$95,0 \%$ Güven Aralığı B } & \multicolumn{2}{l}{ Korelasyon } & & \multicolumn{2}{l}{ Doğrusallık İstatistikleri } \\
\hline Alt Sınır & Üst Sınır & Sıfır Noktası & Kısım & Bölüm & Tolerans & VIF \\
1,535 & 2,177 & & & & & \\
,- 078 &, 094 &, 535 &, 009 &, 006 &, 471 & 2,124 \\
, 573 &, 752 &, 729 &, 587 &, 496 &, 471 & 2,124 \\
\hline
\end{tabular}

Tablo 2‘de görüldüğü üzere 2 bağımsız değişkeninde VIF değerleri 2.5'in altındadır. Bu bize bağımsız değişkenler arasında korelasyon olmadığı sonucunu verir (Allison, 1999).

Tablo 3. Öğrenci Memnuniyetinin Yordanmasına İlişkin Çoklu Regresyon Analizi Sonuçları

\begin{tabular}{|c|c|c|c|c|c|}
\hline & B & $\begin{array}{l}\text { Standar } \\
\text { Hata }\end{array}$ & Beta & $\mathrm{T}$ & $\mathrm{P}$ \\
\hline Sabit & 1,856 & ,163 & & 11,365 &, 000 \\
\hline Teknoloji Kabulü & ,008 & ,044 & ,009 & 189 &, 850 \\
\hline Topluluk Hissi & 662 & ,046 & ,722 & 14,538 & ,000 \\
\hline
\end{tabular}

$\mathrm{R}=0.729 \quad \mathrm{R} 2=0.529$

$\mathrm{F}=228.761 \quad \mathrm{P}=.000$

H1'e cevap aramak için yapılan çoklu regresyon analizi sonucunda teknoloji kabulü ve topluluk hissinin, öğrencilerin uzaktan eğitim memnuniyetini yordayıp, yormadığ 1 sonucuna varılmıştır. Analiz sonuçlarına göre teknoloji kabulü ve topluluk hissi puanları birlikte, öğrencilerin uzaktan eğitime yönelik memnuniyetleri ile yüksek düzeyde ve anlamlı bir ilişki vermektedir $(\mathrm{R}=0,729, \mathrm{R} 2=0,529, \mathrm{p}<, 01)$. Teknoloji kabulü ve topluluk hissi uzaktan eğitimde öğrenci memnuniyetinin yaklaşık \%53'ünü açıklamaktadır. Bu sonuç büyük bir etki olduğunu ortaya koymaktadır. $\beta$ değerleri ve $p$ değerlerine bakıldığında teknoloji kabulünün $(\beta=0.008$, $\mathrm{p}>0.01$ ) bu duruma göre uzaktan eğitime yönelik memnuniyetlerine anlamlı bir etkisi saptanmamıştır. Topluluk hissi bağımsız değişkeninin $\beta$ değerlerine bakıldığında $(\beta=0.662$, $\mathrm{p}<0.01$ ) olarak belirlenmiş ve bu duruma göre uzaktan eğitime yönelik memnuniyetlerine anlamlı ve pozitif bir etkisi saptanmıştır.

H2: Çevrimiçi öğrenme sistemleri kabul ölçeği alt boyutları ve topluluk hissi ölçeği alt boyutları bir arada KKTC'de öğrenim gören öğrencilerin memnuniyetine anlamlı bir şekilde yordamakta midir?

Tablo 4. Korelasyon Tablosu

\begin{tabular}{|c|c|c|c|c|c|c|}
\hline & & Memnuniyet & $\begin{array}{l}\text { Algilanan } \\
\text { Yarar }\end{array}$ & $\begin{array}{l}\text { Algilanan } \\
\text { Kolaylık }\end{array}$ & Duyuşsal & Eylemsel \\
\hline \multirow{5}{*}{$\begin{array}{l}\text { Pearson } \\
\text { Korelasyonu }\end{array}$} & Memnuniyet & & ,503 & ,506 & ,705 & ,626 \\
\hline & Algilanan Yarar & & & ,743 & ,755 & ,540 \\
\hline & $\begin{array}{l}\text { Algilanan } \\
\text { Kolaylık }\end{array}$ & & & & ,620 & 439 \\
\hline & Duyuşsal & & & & & 696 \\
\hline & Eylemsel & & & & & \\
\hline
\end{tabular}

Korelasyon tablosu sonuçlarına bakıldığında 0.800 ve üstünde bir sonuç olmadığı için korelasyon olan bir değişken olmadığı tespit edilmiştir (Yaratan, 2017). 
Tablo 5. Öğrenci Memnuniyetinin Yordanmasına İlişkin Aşamalı Çoklu Regresyon Analizi Sonuçları

\begin{tabular}{|c|c|c|c|c|c|c|}
\hline Model & & B & Std. Hata & Beta & $\mathrm{t}$ & p. \\
\hline \multirow[t]{2}{*}{1} & Sabit & 1,933 & ,158 & & 12,230 & ,000 \\
\hline & Duyuşsal & ,638 & ,032 & ,705 & 19,971 & 000 \\
\hline \multirow[t]{3}{*}{2} & Sabit & 1,848 & ,153 & & 12,056 & ,000 \\
\hline & Duyuşsal & ,473 & ,043 &, 522 & 11,005 &, 000 \\
\hline & Eylemsel & , 198 & ,036 & ,262 & 5,528 &, 000 \\
\hline \multirow[t]{4}{*}{3} & Sabit & 1,655 &, 170 & & 9,708 &, 000 \\
\hline & Duyuşsal & ,413 & ,049 & ,456 & 8,444 & 000 \\
\hline & Eylemsel & , 197 & ,036 & ,261 & 5,531 & ,000 \\
\hline & $\begin{array}{l}\text { Algilanan } \\
\text { Kolaylık }\end{array}$ & ,094 & ,037 & , 109 & 2,529 & ,012 \\
\hline \multirow[t]{5}{*}{4} & Sabit & 1,632 & , 168 & & 9,691 & 000 \\
\hline & Duyuşsal & ,498 & 055 &, 550 & 9,139 & ,000 \\
\hline & Eylemsel & ,200 & 035 & ,265 & 5,692 & ,000 \\
\hline & $\begin{array}{l}\text { Algilanan } \\
\text { Kolaylık }\end{array}$ &, 173 & 044 & ,200 & 3,967 & 000 \\
\hline & Algılanan Yarar &,- 165 & ,049 &,- 203 & $-3,369$ & ,001 \\
\hline
\end{tabular}

Tüm bağımsız değişkenlerin uzaktan eğitim öğrenci memnuniyetlerine anlamlı bir etkisi olduğu saptanmıştır. Algılanan yarar dışında tüm bağımsız değişkenler pozitif bir etki gösterirken, algılanan yarar boyutu negatif bir etki sağlamıştır.

Tablo 6. KKTC Öğrencilerinin Memnuniyet Etkisine İlişkin Aşamalı Çoklu Regresyon Model Analiz Sonuçları

\begin{tabular}{|c|c|c|c|c|c|c|c|c|c|}
\hline \multirow[b]{2}{*}{ Model } & \multirow[b]{2}{*}{$\mathrm{R}$} & \multirow[b]{2}{*}{$\begin{array}{l}\mathrm{R} \\
\text { Kare }\end{array}$} & \multirow[b]{2}{*}{$\begin{array}{l}\text { Ayarlanmış R } \\
\text { Kare }\end{array}$} & \multirow{2}{*}{$\begin{array}{l}\text { Tahmin } \\
\text { Std. } \\
\text { Hatas1 }\end{array}$} & \multicolumn{4}{|c|}{ Değişim İstatistiği } & \multirow[b]{2}{*}{$\begin{array}{l}\text { F Değişimi } \\
\text { İçin p }\end{array}$} \\
\hline & & & & & $\begin{array}{l}\mathrm{R} \quad \text { Kare } \\
\text { Değişimi }\end{array}$ & F Değişimi & sd1 & $\mathrm{sd} 2$ & \\
\hline 1 &, $705^{1}$ & ,497 & ,496 & ,98671 & ,497 & 398,830 & 1 & 404 & ,000 \\
\hline 2 &, $730^{2}$ & ,532 &, 530 & ,95248 &, 035 & 30,560 & 1 & 403 & ,000 \\
\hline 3 &, $735^{3}$ &, 540 &, 536 & ,94616 &, 007 & 6,396 & 1 & 402 &, 012 \\
\hline 4 &, $743^{4}$ &, 552 &, 548 & ,93421 &, 013 & 11,352 & 1 & 401 & ,001 \\
\hline
\end{tabular}

Modeller

Model 1: Duyuşsal

Model 2: Duyuşsal, Eylemsel

Model 3: Duyuşsal, Eylemsel, Algılanan Kolaylık

Model 4: Duyuşsal, Eylemsel, Algılanan Kolaylık, Algılanan Yarar

Tablo 6 analiz sonuçlarına göre algılanan kullanım kolaylığı, algılanan yarar, eylemsel ve duyuşsal boyutların öğrenci memnuniyetini anlamlı bir şekilde etki ettiği görülmektedir $(p<0.01)$. Regresyon katsayısı $\beta$ 'ya göre bağımsız değişkenlerin öğrenci memnuniyetini açıklamadaki önem sırası; duyuşsal, eylemsel, algılanan kullanım kolaylığı ve algılanan yarardır. Modele ilk olarak duyuşsal boyutu girmiştir ve tek başına memnuniyeti yaklaşık \%50 açıklamıştır. İkinci olarak 
duyuşsal ve eylemsel birlikte girmiş ve modeli yaklaşık \%53 açıklamıştır. Üçüncü olarak duyuşsal, eylemsel ve algılanan kolaylık birlikte modele giriş yapmış ve yaklaşık modeli \%54 açıklamıştır. Son olarak ise duyuşsal, eylemsel, algılanan kolaylık ve algılanan yarar boyutu girmiştir ve modeli yaklaşık \%55 açıklamışlardır. Verilerden duyuşsal boyutun ise yalnızca kendisinin memnuniyete etkisinin en yüksek olduğu tespit edilmiştir.

H3: Çevrim içi öğrenme sistemleri kabul ölçeği boyutları ve topluluk hissi ölçeği boyutları ile KKTC'de öğrenim gören öğrencilerin memnuniyeti ölçeği boyutları arasında bir şekilde yordamakta midır?

Tablo 7. Kanonik Değişkenlere Ait Korelasyon Değerleri

\begin{tabular}{|c|c|c|c|c|c|c|c|}
\hline & Korelasyon & Eigenvalue & Wilks İstatistik & $\mathrm{F}$ & Num D.F & Denom D.F & p. \\
\hline 1 & ,791 & 1,672 & ,317 & 22,494 & 24,000 & 1382,689 & ,000 \\
\hline 2 & ,355 & , 144 & 846 & 4,555 & 15,000 & 1096,344 & ,000 \\
\hline 3 & 144 & , 021 & 968 & 1,620 & 8,000 & 796,000 & ,115 \\
\hline 4 & 107 & ,012 & ,989 & 1,530 & 3,000 & 399,000 & ,206 \\
\hline
\end{tabular}

Tablo 7 incelendiğinde kanonik korelasyon katsayılarının karesi bağımlı ve bağımsız değişken arasında açıklanan ortak varyansı belirtmektedir. Tablo 7'de hesaplanan korelasyon katsayıları incelendiğinde birinci kanonik korelasyon kümesi korelasyonunun ,791, ikinci kanonik küme korelasyonunun ,355 olduğu görülmektedir. Tablo 7'de görüldüğü üzere dört kanonik kümesi için hesaplanan korelasyon katsayılarının yalnızca ikisinin anlamlı olduğu hesaplanan Wilk's. ve Sig. değerlerine bakılarak söylenebilir $(p<0.05)$. Bu sebeple yalnızca iki korelasyon kümesinin yorumlaması yapılacaktır.

Tablo 8. Set 1 Değişkenlere Ait Standartlaştırılmış Korelasyon Katsayıları

\begin{tabular}{lllll}
\hline Değişken & 1 & 2 & 3 & 4 \\
\hline Algılanan Kolaylık &,- 267 &, 515 &, 124 & $-1,387$ \\
Algılanan Yarar &, 175 &, 897 &,- 901 & 1,270 \\
Eylemsel &,- 369 &,- 701 & $-1,108$ &,- 294 \\
Duyuşsal &,- 658 &,- 436 & 1,584 &, 333 \\
\hline
\end{tabular}

Tablo 8'de görüldüğü üzere birinci kanonik değişkene en fazla katkı sağlayan değişkenin duyuşsal; ikinci kanonik değişkene ise algılanan yarar olduğu görülmektedir.

Tablo 9. Set 2 Değişkenlere Ait Standartlaştırılmış Korelasyon Katsayıları

\begin{tabular}{lllll}
\hline Değiş̧ken & 1 & 2 & 3 & 4 \\
\hline Basılı Materyal &,- 322 &, 174 &,- 965 &,- 609 \\
Yüz Yüze Etkinlikler &, 084 &,- 967 &, 772 &,- 272 \\
Öğr. Öğr. İlişkisi &,- 545 &,- 605 &,- 618 &, 246 \\
Öğr. Öğretmen İlişkisi &, 040 &, 222 &,- 407 &, 182 \\
Çevrimiçi Dersler &,- 233 &, 819 &, 966 & $-1,372$ \\
Teknik Destek &,- 143 &,- 001 &, 581 & 1,729
\end{tabular}

Tablo 9'da görüldüğü üzere birinci kanonik değişkene en fazla katkı sağlayan değişkenin öğrenci-öğrenci ilişkisi; ikinci kanonik değişkene ise yüz yüze etkinlikler olduğu görülmektedir. 
Tablo 10. Set 1 Kanonik Yükler

\begin{tabular}{lllll}
\hline Değişken & 1 & 2 & 3 & 4 \\
\hline Algılanan Kolaylık &,- 706 &, 604 &,- 050 &,- 365 \\
Algılanan Yarar &,- 719 &, 573 &,- 211 &, 332 \\
Eylemsel &,- 850 &,- 294 &,- 437 &, 015 \\
Duyuşsal &,- 948 &, 073 &, 210 &, 228 \\
\hline
\end{tabular}

Her bir kanonik değişken kümelerdeki değişkenlerin korelasyonlarının 0.30'dan büyük olması o değişkenin kümenin bir parçası olduğunun göstergesidir (Tabachnick ve Fidell, 2007). Tablo 10'da gösterildiği üzere birinci kümede sirasıyla duyuşsal, eylemsel, algılanan yarar ve algılanan kolaylık; ikinci kümede algılanan kolaylık ve algılanan yarar kümelerin bir parçasıdır. Tablo 10 incelendiğinde öğrencilerin uzaktan eğitim memnuniyetini en çok etkileyen değişkenin öncelikle duyuşsal olduğu ve daha sonra eylemsel olduğu görülmektedir.

Tablo 11. Set 2 Kanonik Yükler

\begin{tabular}{lllll}
\hline Değişken & 1 & 2 & 3 & 4 \\
\hline Basılı Materyal &,- 813 &,- 079 &,- 020 &,- 205 \\
Yüz Yüze Etkinlikler &,- 470 &,- 619 &, 481 &,- 238 \\
Öğr. Öğr. İlişkisi &,- 906 &,- 197 &,- 164 &, 072 \\
Öğr. Ö̈̆gretmen İlişkisi &,- 766 &, 210 &, 222 &,- 030 \\
Çevrimiçi Dersler &,- 845 &, 305 &, 391 &,- 175 \\
Teknik Destek &,- 821 &, 123 &, 379 &, 323 \\
\hline
\end{tabular}

Tablo 11'de gösterildiği üzere birinci kümede sırasıyla öğrenci-öğrenci ilişkisi, çevrimiçi dersler, teknik destek, basılı materyal, öğrenci öğretmen ilişkisi ve yüz yüze etkinlikler; ikinci kümede yüz yüze etkinlikler ve çevrimiçi dersler kümelerin bir parçasıdır.

\section{TARTISYMA, SONUÇ VE ÖNERILLER}

\subsection{Tartışma ve Sonuç}

Salgın koşullarının ortaya çıkması ve ülkemiz Türkiye'de görülmesi üzerine ülkece hızlı bir eğitim-öğretim yöntemi değişikliğine zorunlu olarak gidilmiştir. Üniversite öğrenci zorunlu olarak tüm derslerine (uygulama ve teorik) uzaktan çevrim içi olarak devam etmek ve sosyal ortamlarından uzaklaşmak zorunda bırakıldı. Bu zorunluluk üniversite öğrencilerinin çevrimiçin öğrenme memnuniyetlerini olumsuz olarak etkilemiştir. Öğrenciler sosyal ortamlarından koparılıp çevrimiçi eğitim yöntemlerini kabul etmekte zorluk yaşamıştır. Araştırmada teknoloji kabulünün üniversite öğrencilerinin uzaktan eğitime yönelik memnuniyetlerine anlamlı bir etkisi olmadığı saptanmıştır. Fakat topluluk hissi öğrencilerin uzaktan eğitime yönelik memnuniyetleri ile yüksek düzeyde anlamlı ve pozitif bir ilişki vermektedir. Ilgaz'ın 2008'de yapmış olduğu Türkiye'de üniversite öğrencilerinin tüm dersleri değil, yalnızca bir teorik ders ile yapılan çevrimiçi öğrenme süreci sonunda ki çalışma sonucuna göre çevrimiçi öğrenme kabul modeli ve topluluk hissinin üniversite öğrencilerinin çevrimiçi uzaktan eğitim memnuniyetlerine yönelik orta düzeyde bir etkisi olduğu saptanmıştır. Günümüz Covid-19 tedbirleri kapsamında uzun zamandır üniversite öğrencilerinin tüm derslerinin çevrimiçi olması ve buna zorunlu olarak katılmak durumunda olmaları sebebiyle artık çevrimiçi dersleri kabul etmedikleri sonucuna varılmaktadir. 
Çevrimiçi öğrenme sistemlerinde duyuşsal değişkenin öğrenmeleri için faydalı bulan üniversite öğrencilerinin uzaktan eğitim araçları ile teorik ve uygulama derslerine yönelik memnuniyetlerinin daha yüksek olduğu sonucu görülmektedir. Duyuşsal, eylemsel ve algilanan kolaylık değişkenlerinin üniversite öğrencilerinin uzaktan eğitime yönelik memnuniyetlerine anlamlı ve pozitif bir etkisi olduğu saptanmıştır. Uzaktan eğitim yöntemi öğrenciler tarafından kolay, eylemsel açıdan elverişli olarak kabul edilmiştir. Fakat algılanan yarar değişkeninin anlamlı ama negatif bir etkisi saptanmıştır. Bu sonuca göre algılanan yarar değişkenin uzaktan eğitime yönelik memnuniyete etkisi olumsuzdur. Üniversite öğrencileri tüm derslerini zorunlu bir şekilde çevrimiçi öğrenme yöntemi ile eğitim öğretim faaliyetlerine devam ettikleri için bunun kendi akademik başarıları açısından yararlı olmadığını söyledikleri sonucuna varılmıştır. Ilgaz'ın 2008 'de yaptığı araştırma da üniversite öğrencileri uzaktan eğitime yönelik memnuniyetlerine algılanan yarar anlamlı bir etki göstermiştir. Bu anlamlı etki tüm derslerin değil sadece bir teorik dersin uzaktan eğitim ile öğrenim sağlanmış bu sonuç doğrultusunda faydalı olduğu fakat tüm derslerin uzaktan eğitim öğretim yöntemi ile gerçekleştirildiğinde yaptı̆̆ımız araştırma sonucunda fayda sağlamadığı sonucu ortaya çıkmıştır. Bu sonuca göre üniversite öğrencilerinin yüz yüze eğitimi daha yararlı gördükleri anlaşılmaktadır. Saltuk ve Güngör'ün (2020) yapmış olduğu çalışmada ise farklı sonuçlar gözlenmiştir. Öğrencilerin dersleri uzaktan eğitim sistemi ile yürütülmesini istediklerini ve bunun nedenini ise öğrencilere sistem ile ilgili olarak yapılan oryantasyonun sisteme yönelik videoların etkili olduğunu belirtmiştir. Kahya'nın (2021) yapmış olduğu araştırmada zorunlu uzaktan eğitim uygulamalarına geçiş yapan 377 öğrencinin katılımıyla gerçekleşen araştırma sonucunda üniversite öğrencilerinin uzaktan eğitim memnuniyet oran $1 \% 39$ olarak tespit edilmiş ve gerçekleştirmiş olduğumuz araştırma sonucunu destekler niteliktedir. Özkan ve Yeşilırmak'ın (2020) çalışmasında kullanım kolaylığı ve algılanan fayda memnuniyeti anlamlı ve olumlu bir şekilde etkilediği sonucuna varılmıştır. Bu sonuç yapılan çalışmamız ile kullanım kolaylığının memnuniyete anlamlı etkisi konusunda paralellik gösterirken, algılanan fayda bağımsız değişkeni sonucu farklılık göstermektedir.

Çevrimiçi uzaktan öğrenme araçları kabul ölçeği ve topluluk hissi boyutlarının memnuniyet boyutları ile ilişkilerine bakıldığında duyuşsal değişken ve algılanan yarar değişkeni boyutlarının en fazla değerleri vermiş değişkenler oldukları saptanmıştır.

\section{2.Öneriler}

- Üniversite öğrencilerinin tüm derslerinin uzaktan çevrim içi olmaması sağlanmalıdır.

- Öğrenciler için firsat eşitliği yaratma neticesinde uzaktan eğitim iyi bir alternatif olsa da her öğrencinin gerekli teknolojik alt yapıya sahip olduğundan emin olunmalıdır.

- Uzaktan çevrimiçi eğitim ile yüz yüze eğitim yöntemleri birbirinden farklıdır, bir çevrimiçi eğitim materyali hazırlar ve derse hazırlık yaparken bu unutulmamalıdır.

- Eğitimde teknoloji kullanımı ve bilgisayar ve öğretim teknolojileri öğretmenliği alanlarına yatırım yapılmalıdır.

- Her bir üniversite bünyesinde eğitim teknolojileri ile ilgili bir uzman bulundurulmalı ve bu uzman yeni çıkan uygulamalar ve Web2 araçları ile ilgili hizmet içi eğitimler vermelidir.

- Uzaktan eğitim süreçlerinde eğitim öğretim faaliyetlerinin etkili olarak yapılmasının yanı sıra ölçme değerlendirme de güvenilirlik önem arz etmektedir. Sınavın güvenilirliğini artırmak için yüz yüze sınav uygulaması tercih edilmelidir.

- Dijital beceriler desteklenmeli, üniversite öğrencilerinin dijital okulyazarlık becerileri ve hızlı bilgiye olduğu kadar doğru bilgiye dijital dünyada ulaşmaları için üniversite müfredatlarında bu dijital okuryazarlık bulundurulmalıdır. 
- Teorik dersler dışında materyal ve laboratuvar gerektiren uygulama dersleri yüz yüze yürütülmelidir.

- YÖK üniversitelerinin uzaktan eğitim yönergeleri ortak olarak belirlenmelidir.

- Üniversite akademisyenlerine Web2 araçlarını kullanabilmeleri için hizmet içi eğitimler verilmeli ve desteklenmelidir.

- Akademisyenler uzaktan eğitim sürecinde olan dezavantajları en düşük seviyeye çekmek için öğretim faaliyetlerinde VR (Sanal gerçeklik) ve AR (Artırılmış gerçeklik teknolojilerinden faydalanmalıdır.

- Uzaktan eğitim dersleri senkron yapılarak interaktif bir öğretim yöntemi seçilmelidir. Senkron dersler kayıt altına alınıp öğrencilerin istediği zaman dersi pekiştirme imkânı sağlanmalıdır.

- Çevrimiçi derslerin daha fazla yarar sağlamaları adına öğretmen ve öğretim üyelerinin Web2 araçlarını daha etkin kullanabilmeleri sağlanmalıdır.

Araştırmacılar için öneriler;

- İlerideki çalışmalarda daha uzun süre uzaktan eğitim ile dersler almış öğrenciler üzerinde yeni bir çalışma yapılabilir.

- Günümüz de Covid-19 önemleri sebebiyle ilkokul, ortaokul ve lise gibi okullarda öğrenim gören öğrenciler ile bu çalışmalar yapılabilir.

- Daha küçük yaştaki öğrencilere ulaş1labilir.

- Üniversite öğrencilerinin uzaktan çevrimiçi ders aldıkları dönem ve örgün eğitim aldıkları dönem akademik başarıları arasında karşılaştırmalar yapılabilir.

- Üniversite öğrencilerinin yalnızca teorik derslerinde uzaktan öğretim yöntemi kullanıldığı zaman bu çalışma tekrar edilebilir.

\section{KAYNAKÇA}

Allison, P. D. (1999). Multiple regression: A primer. Pine Forge Press.

Anderson, J. (2020). The coronavirus pandemic is reshaping education. Quartz. https://qz.com/1826369/how-coronavirus-is-changing-education/

Balıkçıŏlu, N., Öz, D. Ç. ve Işın, N. N. (2019). Üniversite öğrencilerinin uzaktan eğitim derslerindeki memnuniyet araştırması: Aşık Veysel Meslek Yüksekokulu örneği. Cumhuriyet Üniversitesi İktisadi ve İdari Bilimler Dergisi, 20(1), 462-473.

Başar, M., Arslan, S., Günsel, E. ve Akpınar, M. (2019). Öğretmen adaylarının uzaktan eğitim alg1s1. Journal of Multidisciplinary Studies in Education, 3(2), 14-22.

Bozkurt, A. (2020). Koronavirüs (Covid-19) pandemi süreci ve pandemi sonrası dünyada eğitime yönelik değerlendirmeler: Yeni normal ve yeni eğitim paradigması. Açıköğretim Uygulamalart ve Araştırmaları Dergisi, 6(3), 112-142.

Buluk, B. ve Eşitti, B. (2020). Koronavirüs (COVID-19) sürecinde uzaktan eğitimin turizm lisans öğrencileri tarafindan değerlendirilmesi. Journal of Awareness, 5(3), 285-298.

Ertuğ, C. (2020). Coronavirüs (Covid-19) pandemisi ve pedagojik yansımaları: Türkiye'de açık ve uzaktan eğitim uygulamaları. Açıkögretim Uygulamaları ve Araştırmaları Dergisi, 6(2), 11-53. 
Cantemir, V. ve NAT, M. (2019). Çevrimiçi pedagojik formasyon sertifika programının tasarlanmas1, uygulanması ve değerlendirilmesi. Folklor/Edebiyat, 25(97), 91-104.

Enfiyeci, T. ve Filiz, S. B. (2019). Uzaktan eğitim yüksek lisans öğrencilerinin topluluk hissinin çeşitli değişkenler açısından incelenmesi. TÜBAV Bilim Dergisi, 12(1), 20-32.

Ergün, E. ve Kurnaz, F. B. (2017). Çevrimiçi öğrenme ortamlarında sınıf topluluğu hissi ve öğrenci bağlılığı arasındaki ilişki. Kastamonu Eğitim Dergisi, 25(4), 1515-1532.

Hakan, E. ve Karaman, S. (2013). Uzaktan eğitim öğrencilerinin memnuniyet algıları üzerine bir araştırma. Kirıkkale Üniversitesi Sosyal Bilimler Dergisi, 3(1), 36-59.

Karatepe, F., Küçükgençay, N. ve Peker, B. (2020). Öğretmen adayları senkron uzaktan eğitime nasıl bakıyor? Bir anket çalışması. Journal of Social and Humanities Sciences Research, 7(53), 1262-1274.

Gökal, H. ve Adalıer, A. (2021). Akıllı Telefon Bağımlılığı ve Gelecekteki Akıllı Telefon Satın Alma Davranışına Etkisi Ölçeğinin Türkçe'ye uyarlanması: Geçerlilik ve güvenilirlik çalışması. O. Erkmen \& Z. Sakhi (Ed.), 5th International Zeugma Conference on Scientific Researches (s. 195-203 )içinde. Gaziantep.

Gökal, H., Sönmez, A. ve Ercan, O. (2020). Fen bilgisi öğretmen adaylarının eğitsel internet kullanımına yönelik öz yeterlik düzeyi ile bilgisayar destekli eğitime ilişkin tutumlarının farklı değişkenler açısından incelenmesi. Folklor/Edebiyat, 25(97), 47-63.

Haberler: TCCB. (2020, Mart 12). Türkiye Cumhuriyeti Cumhurbaşkanlığı. https://www.tccb.gov.tr/haberler/410/117021 adresinden alındı

Ilgaz, H. (2008). Uzaktan eğitimde teknoloji kabulünün ve topluluk hissinin öğrenen memnuniyetine katkısı. (Yayınlanmamış Yüksek Lisans Tezi). Hacettepe University Graduate School of Science and Engineering. Ankara.

Kahya, V. (2021). Investigation of compulsory distance education practices with integrated technology acceptance models during the coronavirus (COVID-19) pandemic. Business \& Management Studies: An International Journal, 9(2), 737.

Karadağ, E. ve Yücel, C. (2020). Yeni tip Koronavirüs pandemisi döneminde üniversitelerde uzaktan eğitim: Lisans öğrencileri kapsamında bir değerlendirme çalışması. Yükseköğretim Dergisi, 10(2), 181-192.

Karakuş, N., Ucuzsatar, N., Karacaoğlu, M. Ö., Esendemir, N. ve Bayraktar, D. (2020). Türkçe öğretmeni adaylarının uzaktan eğitime yönelik görüşleri. RumeliDE Dil ve Edebiyat Araştırmaları Dergisi, (19), 220-241.

Keskin, M. ve Derya, Ö. (2020). COVID-19 sürecinde öğrencilerin web tabanlı uzaktan eğitime yönelik geri bildirimlerinin değerlendirilmesi. İzmir Katip Çelebi Üniversitesi Sağlık Bilimleri Fakültesi Dergisi, 5(2), 59-67.

Korucuk, B. (2020). Sınıf öğretmenleri gözüyle uzaktan eğitim memnuniyet faktörlerinin derecelendirilmesi yönelik bir çalışma: Giresun ili örneği. Öğretim Teknolojisi ve Hayat Boyu Öğrenme Dergisi, 1(2), 189-202.

Legris, P., Ingham, J., \& Collerette, P. (2003). Why do people use information technology? A critical review of the technology acceptance model. Information \& management, 40(3), 191-204.

Özkan, E. ve Yeşilırmak, S. (2020). Uzaktan eğitim sürecinin Bilgi Sistemleri Başarı Modeli ve Teknoloji Kabul Modeli ile incelenmesi: Ostim Teknik Üniversitesi örneği. Uluslararası Sağllk Yönetimi ve Stratejileri Araştırma Dergisi, 6(3), 639-650. 
Özkılıçcı, G. ve Uysal Cantürk, P. (2020). Bilişsel esneklik ile uzaktan eğitim memnuniyetinin ilişkisi: Negatif duygulanımın aracı rolü. İstanbul Ticaret Üniversitesi Sosyal Bilimler Dergisi, 19(39), 1167 - 1181.

Saltürk, A. ve Güngör, C. (2020). Covid-19 döneminde öğrencilerde topluluk hissi ve çevrimiçi uzaktan eğitimin incelenmesi. Itobiad: Journal of the Human \& Social Science Researches, 9(5).

Tabachnick, B. G., \& Fidell, L. S. (2007). Using multivariate statistics (5th Ed.). Boston, MA: Allyn and Bacon.[Google Scholar].

Telli, S. G. ve Altun, D. (2020). Coronavirüs ve çevrimiçi (online) eğitimin önlenemeyen yükselişi. Üniversite Araştırmaları Dergisi, 3(1), 25-34.

Telli, S. G. ve Altun, D. (2021). Coronavirus (Covid-19) pandemisi döneminde çevrimiçi öğrenme. Üniversite Araştırmaları Dergisi, 4(2), 90-107.

Yamamoto, G. T., Özgeldi, M., \& Altun, D. (2018). Instructional developments and progress for open and equal access for learning. Open and Equal Access for Learning in School Management, 117-143.

Yaratan, H. (2017). Sosyal bilimler için temel istatistik SPSS uygulamalı. Anı Yayıncılık.

\section{EXTENDED ABSTRACT}

\section{Introduction}

Distance education has been increasing in recent years, geographical barriers, increasing need for education and time constraints, etc. It has become a highly demanded option by individuals for reasons such as. With the coronavirus (Covid-19) pandemic that emerged in Wuhan, China on December 1, 2019, the importance of distance education has increased even more by experiencing the transition to compulsory distance education at all education levels. The coronavirus spread to wide geographies in a very short time and showed its effect on all countries of the world. This process has also affected education. The first precaution taken regarding education was to close the schools and suspend face-to-face education. Educational institutions around the world have started joint studies with non-governmental, private sector partners and international organizations to provide distance education to ensure the continuity of learning (Can, 2020).

When studies on distance education are examined, it is seen that this concept has advantages and disadvantages for teachers and students. In the study by Eygü and Karaman in 2013, the advantages and disadvantages of distance education were explained in items.

In this pandemic process, distance education provided the continuity of education life for students despite all its disadvantages. Although the distance education system is seen as an alternative to formal education by educators and students, this system is as effective as face-toface education (Başar, Arslan, Günsel \& Akpınar, 2019).

\section{Method}

In this study, it has been investigated whether there is a meaningful relationship between technology acceptance and the contribution of community feeling to the satisfaction of students who are compulsory distance education in KKTC. For this reason, a descriptive and relational research model was preferred in the research. During the research process, "Multiple regression analysis", "multi-step regression analysis" and "canonical correlation analysis" were used in the data analysis collected. SPSS 24 software was used during the analysis of the data. 
The universe of the research consists of university students studying in the KKTC. The sample of the study consisted of 406 university students studying at Cyprus International University in the KKTC in the fall semester of 2020-2021.

\section{Finding}

The questionnaire form used in this study was made online via "Google Forms". Scales were applied and collected online. Data collection tools consist of four parts; Personal (demographic) information survey, Online learning systems acceptance scale, Community feeling scale, Satisfaction scale.

$43.8 \%$ of the participants are men and $56.2 \%$ are women. $92.4 \%$ of the participants are under 25 years old, $5.9 \%$ are between 26-35 years old, $0.2 \%$ are between $36-45$ years old and $1.5 \%$ are 45 years old and above. $0.4 \%$ of respondent's nationals of the Republic of Turkey, the Turkish Republic of Northern Cyprus 9.4\%, and 0.2\% consists of other nationalities. $65.0 \%$ of the participants use computers, $3.2 \%$ tablets, and $31.8 \%$ smartphones to access distance education lessons. In addition, in this study, it was found whether there is a significant relationship between technology acceptance and the contribution of community feeling to the satisfaction of students receiving distance education.

\section{Discussion and Conclusion}

In the study, it was determined that technology acceptance did not have a significant effect on university students' satisfaction with distance education. However, the sense of community gives a highly significant and positive relationship with students' satisfaction with distance education. It is seen that university students who find the affective variable useful for learning in online learning systems have higher satisfaction with their distance education tools and theoretical and practical courses. While effective, operational, and perceived convenience variables have a significant and positive effect on university students' satisfaction with distance education, the variable of perceived usefulness has a significant but negative effect. According to this result, it is understood that university students see face-to-face education as more beneficial.

When the relationships between the dimensions of online distance learning tools acceptance scale and community feeling and satisfaction dimensions were examined, it was determined that the dimensions of the affective variable and perceived usefulness variable were the variables that gave the highest values. 